\title{
PLAGIORCHIS VICENTEI, SP.N. (TREMATODA, PLAGIORCHIIDAE) A NEW TREMATODE FROM HEMIDACTYLUS MABOUIA (MOREAU DE JONNĖS) (LACERTILIA, GEKKONIDAE)
}

\author{
Henrique de Oliveira Rodrigues ${ }^{1}$
}

\begin{abstract}
Plagiorchis vicentei, sp.n. is described from the small intestine of the lizard, Hemidactylus mabouia (Moreau de Jonnès, 1818), from Teresópolis, Rio de Janeiro, Brasil. The new species differs from $P$. didelphidis (Parona, 1896) by the smaller size of body, by the presence of spinous tegument and ventral sucker smaller than oral sucker: from $P$. parumbursaus Freitas \& Dobhin $\mathbf{J r}$., 1961 by the smaller size of body and suckers and the bigger size of eggs; from $P$. rangeli Artigas \& Zerpa, 1961 by the bigger size of suckers and eggs; and from $P$. freitasi Vicente, 1978 by the smaller size of body, by the higger size of eggs and by the different position of gonads that in the new species are close to the ventral sucker.

KEY WORDS. Trematoda, Plagierchis, Lacertilia, Hemidactylus. Brazil
\end{abstract}

Hemidactylus mabouia (Moreau de Jonnès, 1818) is a small lizard white ash-coloured with many transverse black bands and 15 to $17 \mathrm{~cm}$ of maximum length. It lives in hot regions and at night comes to the houses where it feeds on insects.

Rodrigues (1970) reviewed the helminths parasites of this lizard. Afterwards, RODRIGUes \& SANTOS (1974), RODRIGUes (1986) and RODRIGUes et al. (1990) studied helminths from this same host. In this paper, a new species of trematode is described from a $H$. mabouia captured in Teresópolis, Rio de Janeiro.

\section{MATERIAL AND METHODS}

Four lizards were examined; one out of them was positive for trematodes. Samples were recovered in a $0,8 \% \mathrm{NaCl}$ solution, fixed in Railliet \& Henry solution, under a cover glass, with application of slight pressure, stained in alcoholic carmine, dehydrated in ethyl alcohol, cleared in beechwood creosote, and mounted in Canada balsam. Measurements are in millimeters ( $\mathrm{mm})$. Type and voucher specimens were deposited in the Instituto Oswaldo Cruz, Helminthological Collection (CHIOC).

1) Departamento de Helmintologia. Instituto Oswaldo Cruz. Caixa Postal 926. 21045-900 Rio de Janeiro, Rio de Janeiro, Brasil. Research fellow CNPy. 


\section{RESULTS}

\section{Plagiorchis vicentei, sp.n.}

Figs 1-2

Body elongate, spinous, 1.73-2.66 long, 0.69-0.98 wide. Oral sucker subterminal, 0.19-0.24 long, 0.21-0.25 wide. Prepharynx 0.037-0.044 long, 0.093-0.111 wide. Pharynx 0.079-0.133 long, 0.133-0.176 wide. Oesophagus short, 0.066-0.166 long. Caeca long, extending to 0.166-0.299 from posterior extremity. Ventral sucker smaller than oral sucker, located in anterior half of body 0.17-0.18 long by 0.16-0.18 wide. Testes oblique, postacetabular, in middle third of body, 0.166-0.299 long, 0.148-0.299 wide. Ovary subsphaerical, pretesticular, close to ventral sucker, 0.179-0.226 long, 0.166-0.199 wide. Mehlis gland present. Genital pore median, anterior to ventral sucker, near posterior end of oesophagus. Cirrus sac present, 0.333-0.432 long, 0.066-0.099 wide. Vitelline follicles lateral, distributed along almost all length of caeca. Uterus intercecal, passing between testes to posterior end of body. Eggs operculated 0.029-0.033 long by 0.014-0.018 wide. Excretory vesicule Y-shaped. Excretory pore subterminal.

Host. Hemidactylus mabouia.

Site. Small intestine.

Locality. BRAzIL, Rio de Janeiro: Teresópolis.

Holotype no. 32,847c and paratypes no. 32,847a-b and d, deposited in the CHIOC (whole mounts).

\section{DISCUSSION}

The genus Plagiorchis Luehe, 1899 includes a large number of species parasitizing amphibians, reptiles, hirds and mammals. In Brazil four species were reported: P. didelphidis (Parona, 1896) Stossich, 1904 in Metachirops opossum (Linnaeus) (mammal) by FreITAS \& LENT (1940), P. parumbursatus Freitas \& Dobbin Jr., 1961 in Molossus major crassicaudatus E. Geoff. (mammal) by Freit AS \& DoBbin (1961), P. rangeli Artigas \& Zerpa, 1961 in Leptodactylus ocellatus (Linnaeus) (amphibiam) by ARTIGAS \& ZERPA (1961), and P. freitasi Vicente, 1978 in Tropidurus torquatus (Wied.) (reptile) by VICENTE (1978).

The new species differs from $P$. didelphidis by the smaller size of body, by the presence of spinous tegument and ventral sucker smaller than oral sucker; from $P$. parumbursatus by the smaller size of body and suckers and the bigger size of eggs; from $P$. rangeli by the higger size of suckers and eggs; from $P$. freitasi by the smaller size of body, by the higger size of eggs and by the different position of gonads that in our species are close to the ventral sucker.

This is the second report of Plagiorchis in a reptilian host in Brazil; the first was made by VICENTE (1978).

This species is named after Dr. Joaquim Julio Vicente of the Department of Helmonthology of Instituto Oswaldo Cruz, Rio de Janeiro 


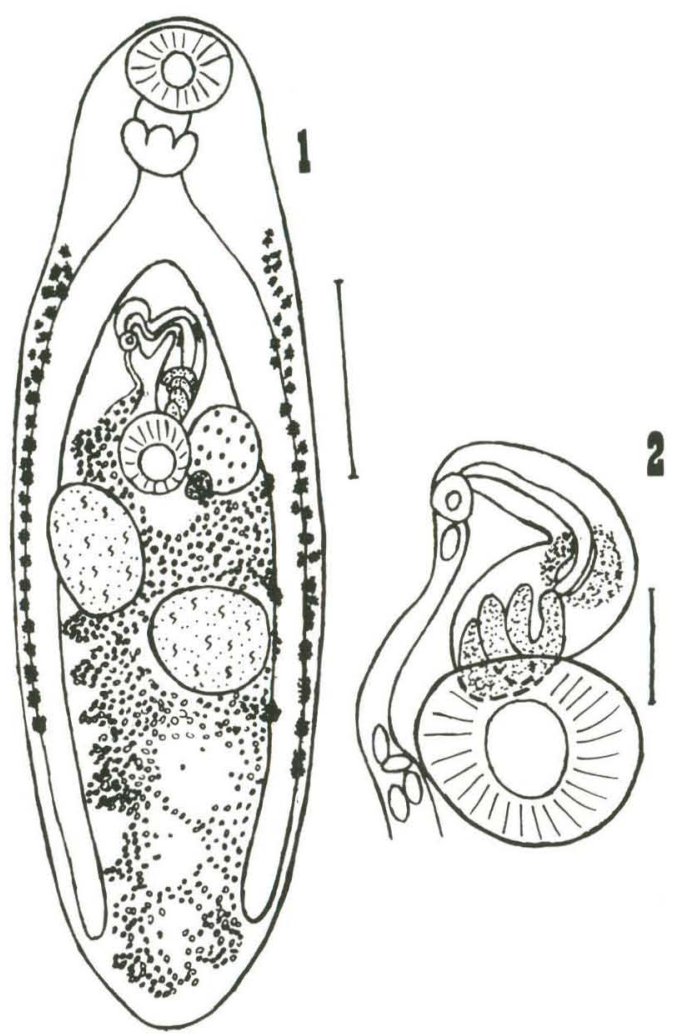

Figs 1-2. Plagiorchis vicentei, sp.n. (1) Total view of the holotype (CHIOC $32.847 \mathrm{e}$; bar $=0.4 \mathrm{~mm})$; (2) terminal genitália (CHIOC $32.847 \mathrm{~d}$; har $=0.1 \mathrm{~mm})$.

\section{BIBLIOGRAPHIC REFERENCES}

Artigas, P.T. \& M.G. Zerpa. 1961. Plagiorchis rangeli sp.n. de Leptodactylus ocellatus (L.) (Trematoda, Plagiorchiidae). An. Fac. Farm. Odont. Univ. S. Paulo 18 (1): 25-28.

Freitas, J.F.T. \& J.E. DobBIn JR. 1961. Plagiorchis parumbursatus sp.n., trematodeo parasito de quiroptero. Atas Soc. Biol. Rio de Janeiro 5 (4): 22-24.

Freitas, J.F.T. \& H. Lent. 1940. Plagiorchis didelphidis (Parona, 1896) um parasito pouco conhecido de marsupiais. Arq. Inst. Benjamin Baptista, Rio de Janeiro, 6: 131-135.

Rodrigues, H.O. 1970. Estudo da fauna helmintológica de Hemidactylus mabouia (M. de J.) no Estado da Guanahara. Atas Soc. Biol. Rio de Janeiro 12 (Supl.): 15-23.

1986. Contribuição ao estudo da fauna helmintológica de vertebrados de Nova Iguaçu, RJ. Atas Soc. Biol. Rio de Janeiro 26: 27-28. 
Rodrigues, H.O.; S.S. Rodrigues \& Z. Faria. 1990. Contribution to the knowledge of the helminthological fauna of vertebrates of Maricá, Rio de Janeiro State, Brazil. Mem. Inst. Oswaldo Cruz 85: 115-116.

Rodrigues, H.O. \& E. Santos. 1974. Notas sobre dois helmintos parasitos de répteis. Atas Soc. Biol. Rio de Janeiro 17: 55-58.

Vicente, J.J. 1978. Helmintos de Tropidurus (Lacertilia, Iguanidae) da Coleção Helmintológica do Instituto Oswaldo Cruz. I. Trematoda, Cestoda, Acanthocephala, Linguatulida. Atas Soc. Biol. Rio de Janeiro 19: 71-78.

Recebido em 30.III.1994; aceito em 11.X.1994. 